\title{
Plant Growth Promoting Endophytic Bacteria of Coffea canephora and Coffea arabica L. in UB Forest
}

\author{
Esti Rizkiana Pratiwi ${ }^{1 *}$, Tri Ardyati ${ }^{2}$, Suharjono Suharjono ${ }^{2}$ \\ ${ }^{1}$ Master Program of Biology, Department of Biology, Faculty of Mathematics and Natural Sciences, University of \\ Brawijaya, Malang, Indonesia \\ 2Department of Biology, Faculty of Mathematics and Natural Sciences, University of Brawijaya, Malang, Indonesia
}

\begin{abstract}
Plant Growth Promoting (PGP) Endophytic bacteria are used as an alternative biofertilizer to support soil health and plant productivity. This research aimed to isolate, analyze the potential, and identify the endophytic bacteria of Robusta and Arabica coffee plants as biofertilizer agents. Endophytic bacteria were isolated from the roots of coffee plants and tested for their potential to produce IAA, phosphate-solubilizing, and nitrogen fixation. Potential endophytic bacterial isolates were identified based on 16S rDNA sequence similarity. Total isolates from Robusta coffee consisting of ten IAAproducing bacteria, eight phosphate-solubilizing, and seven nitrogen fixation bacteria isolates. Total isolates from Arabica coffee roots were 12 isolates of IAA-producing bacteria, seven isolates of phosphate-solubilizing bacteria, and six isolates of nitrogen fixation bacteria. The highest potential of the isolate from Robusta roots was SS.E2 isolate to produce IAA $110.73 \mu \mathrm{g} \cdot \mathrm{mL}^{-1}$; SS.P3 isolate to dissolve phosphate $4.42 \mu \mathrm{g} \cdot \mathrm{mL}^{-1}$, and SS.N2 isolate to produce ammonium $3.15 \mu \mathrm{g} \cdot \mathrm{mL}^{-1}$. The highest potential of the isolate from Arabica roots was SW.E9 isolate to produce IAA up to 257.16 $\mu \mathrm{g} . \mathrm{mL}^{-1}$; SW.P5 isolate to dissolve phosphate up to $4,55 \mu \mathrm{g} \cdot \mathrm{mL}^{-1}$; and SW.N6 isolate to produce ammonium up to 1.16 $\mu \mathrm{g} . \mathrm{mL}^{-1}$. Isolates SS.E2, SW.E9, SS.P3, SW.P5, SS.N2, and SW.N6 were respectively identified as Bacillus cereus ATCC 14579, Bacillus cereus ATCC 14579, Rahnella aquatilis B35, Kluyvera intermedia TPY16, Rahnella aquatilis B35, and Pseudomonas tolaasii NCPPB 2192. Potential PGP isolates can be developed as biofertilizer agents for the coffee plant.
\end{abstract}

Keywords: Coffee, Endophytic bacteria, IAA, Nitrogen, Phosphate

\section{INTRODUCTION}

Coffee fruit is used as a popular beverage commodity for the global community. The value of the coffee sale price is determined by its quality. Organic coffee fruit and beverage products have a higher selling price than conventional coffee [1,2]. Robusta and Arabica coffee are agricultural commodities that commercially provide added value economically for the community and government [3].

UB Forest is a land for the conversion of forests into coffee plantations (Agroforestry). Forest land that converted to agricultural land causes a decrease in plant diversity and soil microbes [4]. Soil microbes play an important role in the cycle of elements that increase soil fertility and provide nutrients for plants [5-6]. Decreasing microbial diversity and soil fertility is a major factor in reducing the productivity of coffee plants.

Some species of bacteria have the potential to promote plant growth (Plant Growth Promoting/PGP). PGP microbes associate symbiosis that positively impacts plant health and growth, improves soil quality and nutrient

\footnotetext{
* Correspondence address:

Esti Rizkiana Pratiwi

Email : rizkianaesti@gmail.com

Address : Dept. Biology, University of Brawijaya, Veteran Malang, 65145
}

cycles $[7,8,9]$. Endophytic bacteria associate and colonize plant tissues and play a role in spurring plant growth and development (PGP agents) [10].

Various PGP bacteria are being developed into biofertilizer products as an alternative to synthetic fertilizers. Bacillus subtilis endophytic cocoa beans increased the development of cocoa plants and as an antimicrobial pathogen [11]. Bacillus subtilis LK14 endophytic roots and stems of Solanum lycopersicum can produce IAA and increase root and stem biomass, as well as the amount of chlorophyll $a$ and $b$ [12]. Agrobacterium tumafaciens and Azotobacter vinelandii endophytic sweet potatoes produce IAA [13]. Herbaspirillum endophytic rice plants were able to fix nitrogen and produce IAA [14]. Endophytic bacteria from the leaves, fruits, stems, and roots of Arabica coffee plants are Bacillus, Burkholderia, Clavibacter, Curtobacterium, Escherichia, Micrococcus, Pantoea, Pseudomonas, Serratia, and Stenotrophomonas [15].

The diversity of endophytic bacteria from the roots of coffee plants are widely reported. However, the diversity and potential of endophytic bacteria in coffee plants as PGP agents, especially in UB Forest, have not been studied yet. This study aims to isolate, analyze the potential, and identify potential isolates of Robusta and Arabica coffee root endophytic bacteria from UB Forest as PGP agents. 


\section{MATERIAL AND METHOD \\ Coffee Plant Root Sampling}

Root samples were taken from Arabica and Robusta coffee plants in UB Forest agroforestry land, Malang, East Java Province, Indonesia. UB Forest Agroforestry is located at $07.824545^{\circ} \mathrm{SL}$ and $112.578390^{\circ} \mathrm{EL}$ and $07.821705^{\circ} \mathrm{SL}$ and $112.577551^{\circ} \mathrm{EL}$. Three samples were taken from each type of coffee plant. Each sample was a composite root of three plants. The root sample of each plant is the secondary roots with a healthy tip at a depth $\pm 10 \mathrm{~cm}$. Root samples were put in plastic bags and stored in isothermic boxes/cool boxes.

Isolation of Endophytic Bacteria in Coffee Plants

The endophytic bacterial roots of coffee plants were isolated according to the method of previous studies $[15,16,17]$. The root sample of the coffee plant is cut off $10 \mathrm{~cm}$ long, then washed with running water and rinsed with sterile distilled water. The roots are cut into pieces with a length of $\pm 2 \mathrm{~cm}$ and then sterilized by immersing the surface in Ethanol $70 \%$ for one minute, sodium hypochlorite $5.25 \%$ for 5 minutes, and Ethanol $70 \%$ half minutes and then washed three times in sterile distilled water for one each minute. A 10 gram sterile root sample plus $90 \mathrm{~mL}$ of sterile physiological saline solution $(0.85 \% \mathrm{NaCl})$ is blended to homogeneous. The root sample suspension is made in a dilution series of up to $10^{-6}$. Each $0.1 \mathrm{~mL}$ sample suspension was inoculated in a pour plate on Tryptic Soy Agar (TSA) media containing $1 \mu \mathrm{g} \cdot \mathrm{mL}^{-1}$ L-Tryptophan and then incubated at $28^{\circ} \mathrm{C}$ for 48 hours to obtain a culture of IAA-producing endophytic bacterial isolates [16-17].

Phosphate solubilizing endophytic bacteria were isolated by method of previous studies [1920]. A root sample suspension of $0.1 \mathrm{~mL}$ was inoculated by pour plate on a Pikovskaya agar medium consisting of Glucose $\left(5 \mathrm{~g}^{-1} \mathrm{~L}^{-1}\right) ; \mathrm{Ca}_{3}\left(\mathrm{PO}_{4}\right)_{2}$ (2.5 g. $\left.\mathrm{L}^{-1}\right) ; \mathrm{KCl}\left(0.1\right.$ g.L $\left.\mathrm{L}^{-1}\right) ;(\mathrm{NH} 4)_{2} \mathrm{SO}_{4}\left(0.25\right.$ g. $\left.\mathrm{L}^{-1}\right)$; $\mathrm{NaCl} \quad\left(0.1 \quad\right.$ g. $\left.\mathrm{L}^{-1}\right) ; \quad \mathrm{MgSO}_{4} .7 \mathrm{H}_{2} \mathrm{O} \quad\left(0.025 \quad\right.$ g. $\left.\mathrm{L}^{-1}\right) ;$ $\mathrm{MnSO}_{4} . \mathrm{H}_{2} \mathrm{O}\left(0.25\right.$ g. $\left.\mathrm{L}^{-1}\right) ; \mathrm{FeSO}_{4} .7 \mathrm{H}_{2} \mathrm{O}\left(0.25\right.$ g. $\left.\mathrm{L}^{-1}\right)$; yeast extract $\left(0.25 \mathrm{~g} . \mathrm{L}^{-1}\right)$ and agar $\left(15 \mathrm{~g} . \mathrm{L}^{-1}\right)$, then incubated at $28^{\circ} \mathrm{C}$ for 72 hours.

Nitrogen-fixing endophytic bacteria were also isolated [20]. A root sample suspension of $0.1 \mathrm{~mL}$ was inoculated on $\mathrm{N}$-free media (without Bromothymol blue) consisting $\mathrm{KH}_{2} \mathrm{PO}_{4}\left(0.5\right.$ g. $\left.\mathrm{L}^{-1}\right)$; $\mathrm{FeCl}_{3} .6 \mathrm{H}_{2} \mathrm{O}\left(0.015\right.$ g. $\left.\mathrm{L}^{-1}\right) ; \mathrm{MgSO}_{4} .7 \mathrm{H}_{2} \mathrm{O}\left(0.2\right.$ g. $\left.\mathrm{L}^{-1}\right)$; $\mathrm{NaCl}$ (0.1 g.L $\left.\mathrm{L}^{-1}\right)$; DL-Malic Acid (5 g. $\left.\mathrm{L}^{-1}\right) ; \mathrm{KOH}(4.8$ g. $\left.\mathrm{L}^{-1}\right)$, yeast extract $\left(0.05 \mathrm{~g} . \mathrm{L}^{-1}\right)$ and agar $\left(15 \mathrm{~g} . \mathrm{L}^{-1}\right)$, then incubated at $28^{\circ} \mathrm{C}$ for 7 days. Each IAA- producing endophytic bacterial isolate, phosphate-solubilizing, and nitrogen fixation was purified by spread plate.

\section{Bacterial Potency Assay for Producing IAA}

Each endophytic bacterial isolate was tested for its potential in producing IAA hormones $[16,20]$. An oose loop full isolate culture was inoculated into $25 \mathrm{~mL}$ of Tryptic Soy Broth (TSB) media containing $2 \%$ of L-Tryptophan $\left(1 \mu \mathrm{g} \cdot \mathrm{mL}^{-1}\right)$ and incubated at $28^{\circ} \mathrm{C}$ for 48 hours. Each cell culture with $O D 1,0$ as much as $5 \mathrm{~mL}$ was inoculated into $50 \mathrm{~mL}$ of TSB media containing $2 \%$ of L-Tryptophan (1 $\left.\mu \mathrm{g} \cdot \mathrm{mL}^{-1}\right)$ and then incubated at $28^{\circ} \mathrm{C}$ for 72 hours. Bacterial culture was taken $2 \mathrm{~mL}$ every 24 hours and then centrifuged at $10.000 \mathrm{rpm}$ for 10 minutes. The 2 $\mathrm{mL}$ supernatant was added $4 \mathrm{~mL}$ of Salkowski reagent and incubated in a dark room for 30 minutes until it turned pink. The suspension was measured for absorbance at a wavelength of 535 $\mathrm{nm}$, then the IAA concentration is calculated based on the IAA standard curve.

\section{Bacterial Potency Assay for Phosphate Solubilizing}

Each endophytic bacterial isolate was tested for its potential in dissolving phosphate $[19,20]$. An oose loop full isolate culture was inoculated into $25 \mathrm{~mL}$ liquid Pikovskaya media $(\mathrm{pH}$ 7) containing $0.5 \%$ Tricalcium Phosphate (TCP) and incubated at $28^{\circ} \mathrm{C}$ for 72 hours. Each isolate culture (OD 1,0) was inoculated as much as $5 \mathrm{~mL}$ into $50 \mathrm{~mL}$ liquid Pikovskaya media $(\mathrm{pH}$ 7) containing $0.5 \% \mathrm{TCP}$ and incubated at $28^{\circ} \mathrm{C}$ for 72 hours. Bacterial culture was taken $2 \mathrm{~mL}$ every 24 hours and then centrifuged at $10.000 \mathrm{rpm}$ for 20 minutes. Supernatant $1 \mathrm{~mL}$ was added with 10 $\mathrm{mL}$ Chloromolybdate reagent and $0.1 \mathrm{~mL}$ Chlorostannous acid. The suspension was added with sterile distilled water up to a volume of 50 $\mathrm{mL}$ then incubated for 10 minutes. The sample suspension was measured for absorbance at a wavelength of $690 \mathrm{~nm}$ and the concentration was calculated based on a standard phosphate curve.

\section{Bacterial Potency Assay for Nitrogen Fixation}

Each endophytic bacterial isolate was tested for potential fixation of nitrogen [20]. A 1 oose loop full isolate culture was inoculated into 25 $\mathrm{mL}$ liquid $\mathrm{N}$-Free (without Bromothymol blue) media and incubated at $28^{\circ} \mathrm{C}$ for 7 days. Bacterial cultures (OD 0,6$)$ of $5 \mathrm{~mL}$ were inoculated into 50 $\mathrm{mL}$ of liquid $\mathrm{N}$-Free media and incubated at $28^{\circ} \mathrm{C}$ for 7 days. Bacterial culture was taken $2 \mathrm{~mL}$ every 2 days and then added $10 \mu \mathrm{LnSO}_{4}$ and $2.5 \mu \mathrm{L}$ $\mathrm{NaOH} 2 \mathrm{~N}$ were incubated for 30 minutes until the 
culture became clear. The suspension is centrifuged at $10.000 \mathrm{rpm}$ for 10 minutes. A $1 \mathrm{~mL}$ supernatant was added with $0.5 \mathrm{~mL}$ of Nessler's reagent and sterile distilled water up to $5 \mathrm{~mL}$ volume. The suspension is incubated for 30 minutes until it is yellow. The suspension was measured for absorbance at a wavelength of 425 $\mathrm{nm}$ and ammonium concentration was calculated based on the standard ammonium curve.

\section{Identification of Potential Endophytic Bacteria Based on 16S rDNA Sequences}

Potential endophytic bacterial isolates of PGP agents were isolated by chromosomal DNA according to the modification of the ZR Fungal/ Bacterial DNA MiniPrep Kit method. The 16S rDNA sequences were amplified using universal primers $27 f$ ( 5 '-GAG AGT TTG CTG GCT ATC CAG3') and 1492r (5 '-CTA CGG CTA TGT CCT TAC GA3'). The $16 \mathrm{~S}$ rDNA sequence was amplified with a PCR mix composition consisting of a $25 \mu \mathrm{L}$ master mix, $5 \mu \mathrm{L}$ DNA template (50 ng. $\mathrm{mL}^{-1}$ ), each primer $2 \mu \mathrm{L}(10 \mathrm{pmol})$, and Nuclease free water $16 \mu \mathrm{L}$. The PCR program for 165 rDNA amplification consisted of Pre-denaturation at $94^{\circ} \mathrm{C}$ (5 minutes) followed by 35 cycles including denaturation $\left(94^{\circ} \mathrm{C} ; \quad 0.5\right.$ minutes), annealing $\left(55^{\circ} \mathrm{C} ; 0.5\right.$ minutes), extension $\left(72^{\circ} \mathrm{C} ; 1.5\right.$ minutes) and postextension $\left(72^{\circ} \mathrm{C}, 7\right.$ minutes) [20-21]. The $16 \mathrm{~S}$ rDNA sequence was sequencing at First Base, Malaysia. The $16 \mathrm{~S}$ rDNA was alignment sequence with the reference sequence, and the phylogeny tree was constructed based on the Maximum-
Likelihood algorithm, with 1000 bootstraps using the MEGA 6.0 program [20,22,23].

\section{RESULT AND DISCUSSION \\ IAA-producing Endophytic Bacteria}

IAA-producing endophytic bacteria that were isolated from the roots of Robusta and Arabica Coffee plants were as many as 10 isolates and 12 isolates, respectively. Each endophytic bacterial isolate has a different potential $(p<0.05)$ in producing IAA hormones (Fig.1). Figure 1 shows SS.E2 isolates from endophytic roots Robusta coffee that producing IAA hormone with the highest concentration up to $110.73 \mu \mathrm{g} \cdot \mathrm{mL}^{-1}$ at 72 hours incubation time ( $p<0.05)$ among the endophytic bacterial isolates of Robusta Coffee plant roots. SW.E9 isolates from endophytic roots Arabica coffee were able to produce IAA hormone with the highest concentration up to $257.16 \mu \mathrm{g} \cdot \mathrm{mL}^{-1}$ in 72 hours incubation time ( $p$ $<0.05$ ) among the endophytic bacterial isolates of Arabica Coffee plant roots.

SS.E2 and SW.E9 isolates were able to produce higher IAA than Bacillus aryabhattai MBN3 endophytic Vigna radiata root, which produced IAA $92.03 \mu \mathrm{g} \cdot \mathrm{mL}^{-1}$ [24]. The Ltryptophan compound as an IAA precursor that was added to the media can increase the production of IAA, and bacterial culture in the media will trigger auxin biosynthesis (IAA) [25]. The addition of L-tryptophan as much as 0.2 $\mathrm{mg} \cdot \mathrm{mL}^{-1}$ produced the highest IAA of 62.92 $\mu \mathrm{g} \cdot \mathrm{mL}^{-1}$ in SB28 isolates [18].

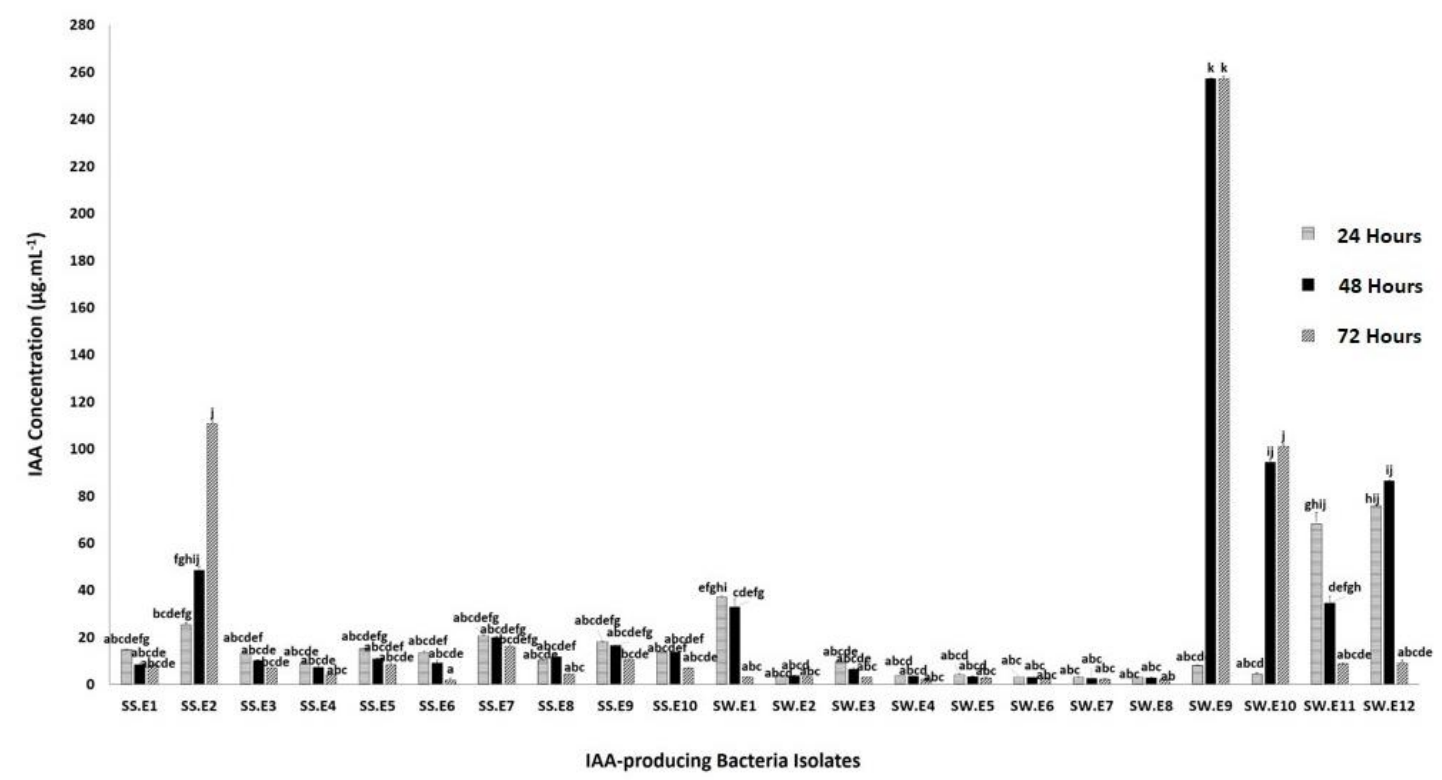

Figure 1. The concentration of IAA hormone produced by IAA-producing bacteria at various times incubation. *Data were expressed as mean \pm standard deviation of three replications using Two-Way ANOVA analysis at $\alpha=0.05$. The notation above of the different histograms states the difference in potential between isolates $(p<0.05)$. 


\section{Phosphate Solubilizing Endophytic Bacteria}

Phosphate Solubilizing Endophytic Bacteria from roots of Robusta Coffee and Arabica Coffee plants were successfully isolated as many as 8 isolates and 7 isolates, respectively. Each isolate can dissolve different phosphates (Fig. 2). Figure 2 shows the isolates of SS.P3 from endophytic roots Robusta Coffee plants in 48 hours incubation time had the highest potential $(p<0.05)$ to dissolving phosphate up to 4.42 $\mu \mathrm{g} . \mathrm{mL}^{-1}$. SW.P5 isolates from endophytic roots Arabica Coffee plant has the highest potential $(p<0.05)$ dissolving phosphate with a concentration up to $4.55 \mu \mathrm{g} \cdot \mathrm{mL}^{-1}$ at 48 hours incubation time.

The concentration of SS.P3 and SW.P5 isolates were lower than EB14 isolates that can dissolve phosphate for $12.54 \mu \mathrm{g} \cdot \mathrm{mL}^{-1}$ with an incubation time of 48 hours [26]. In general, bacteria can dissolve phosphate because it produces organic acids, which reduce the $\mathrm{pH}$ of the media [27]. By using tricalcium phosphate (TCP) as a $P$ source in the culture medium, produced the highest phosphate concentration reaching $764.7 \mu \mathrm{g} \cdot \mathrm{mL}^{-1}$ [28].

\section{Nitrogen-Fixing Endophytic Bacteria}

A total of 7 isolates and 6 isolates of nitrogenfixing endophytic bacteria were found from the roots of Robusta Coffee and Arabica Coffee, respectively. Each isolate can produce different ammonium (Fig.3). Figure 3 shows that SS.N2 isolate from endophytic roots Robusta Coffee plants has the highest potential ( $p<0.05$ ) producing ammonium up to $3.15 \mu \mathrm{g} \cdot \mathrm{mL}^{-1}$ at the incubation time of 3 days ( 72 hours). The highest ammonium concentration from endophytic roots Arabica Coffee plant is SW.N6 isolate that reached $1.16 \mu \mathrm{g} \cdot \mathrm{mL}^{-1}$ at 7 days incubation time ( $p$ $<0.05)$. The potential of SS.N2 and SW.N6 isolates was almost the same as EB5 isolates in producing $1.6 \mu \mathrm{g} \cdot \mathrm{mL}^{-1}$ ammonium [26]. Molecular nitrogen is modified by endophytic bacteria to be converted into ammonium as a nutrient for the growth of host plants [29].

\section{Potential Endophytic Bacterial Species of PGP Agents}

PGP activity by isolates, which indicated the highest IAA production, was identified as Bacillus cereus ATCC $14579^{\top}$ SS.E2 and SW.E9 isolate. The isolates that had the highest phosphatesolubilizing concentration was identified as Rahnella aquatilis B35 isolate SS.P3 and Kluyvera intermedia TPY16 isolate SW.P5. The highest ammonia production activity was performed by Rahnella aquatilis B35 isolate SS.N2 and Pseudomonas tolaasii NCPPB 2192 isolate SW.N6. The potential isolates have each different potency in their activity as PGP. Each plant has endophytic bacteria that capable of producing biological compounds or secondary metabolites obtained from the transfer host plant to endophytic bacteria [30].

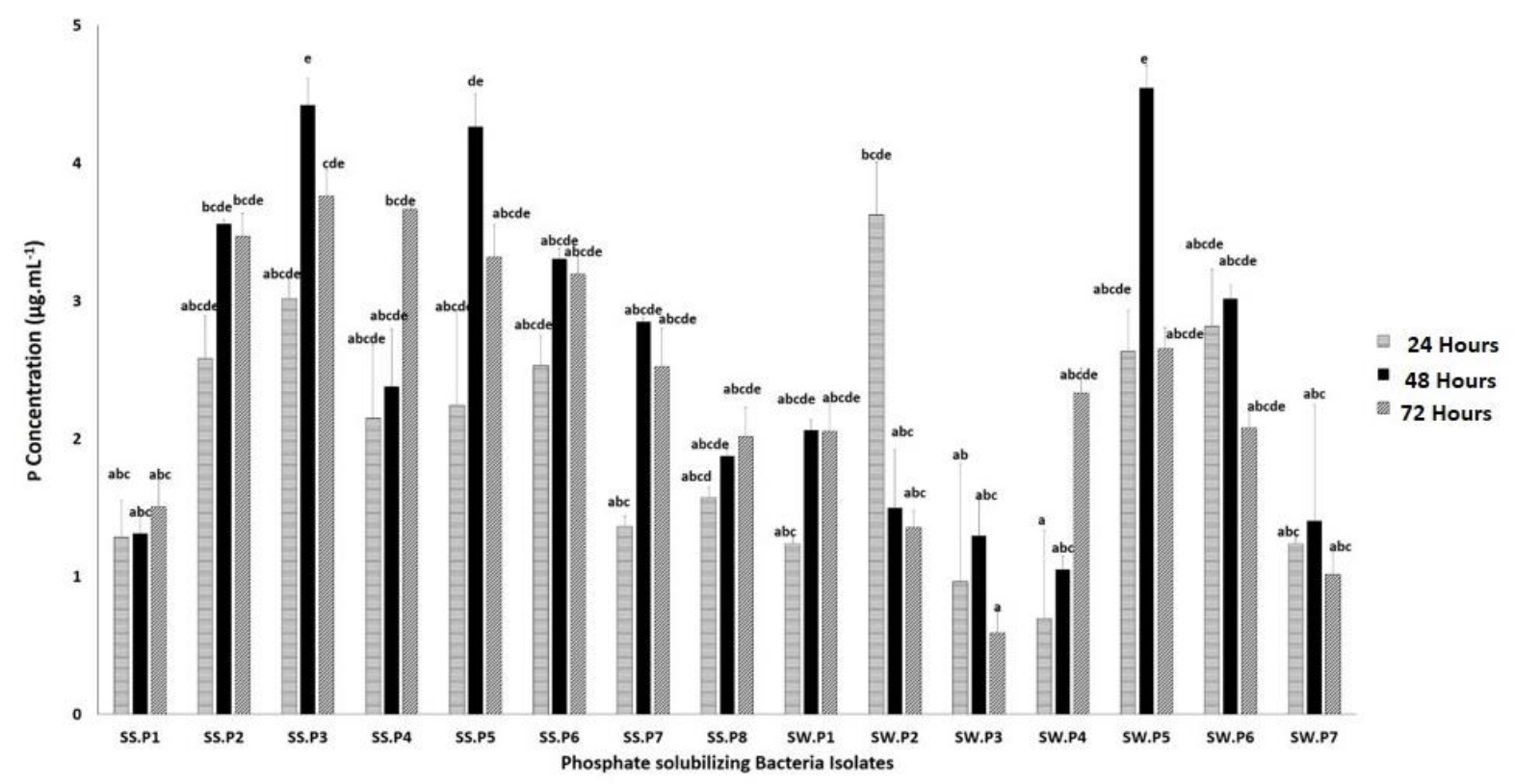

Figure 2. The concentration of Phosphate dissolved by Phosphate solubilizing bacteria at various times incubation. *Data were expressed as mean \pm standard deviation of three replications using Two-Way ANOVA analysis at $\alpha=0.05$. The notation above of the different histograms states the difference in potential between isolates $(p<0.05)$. 


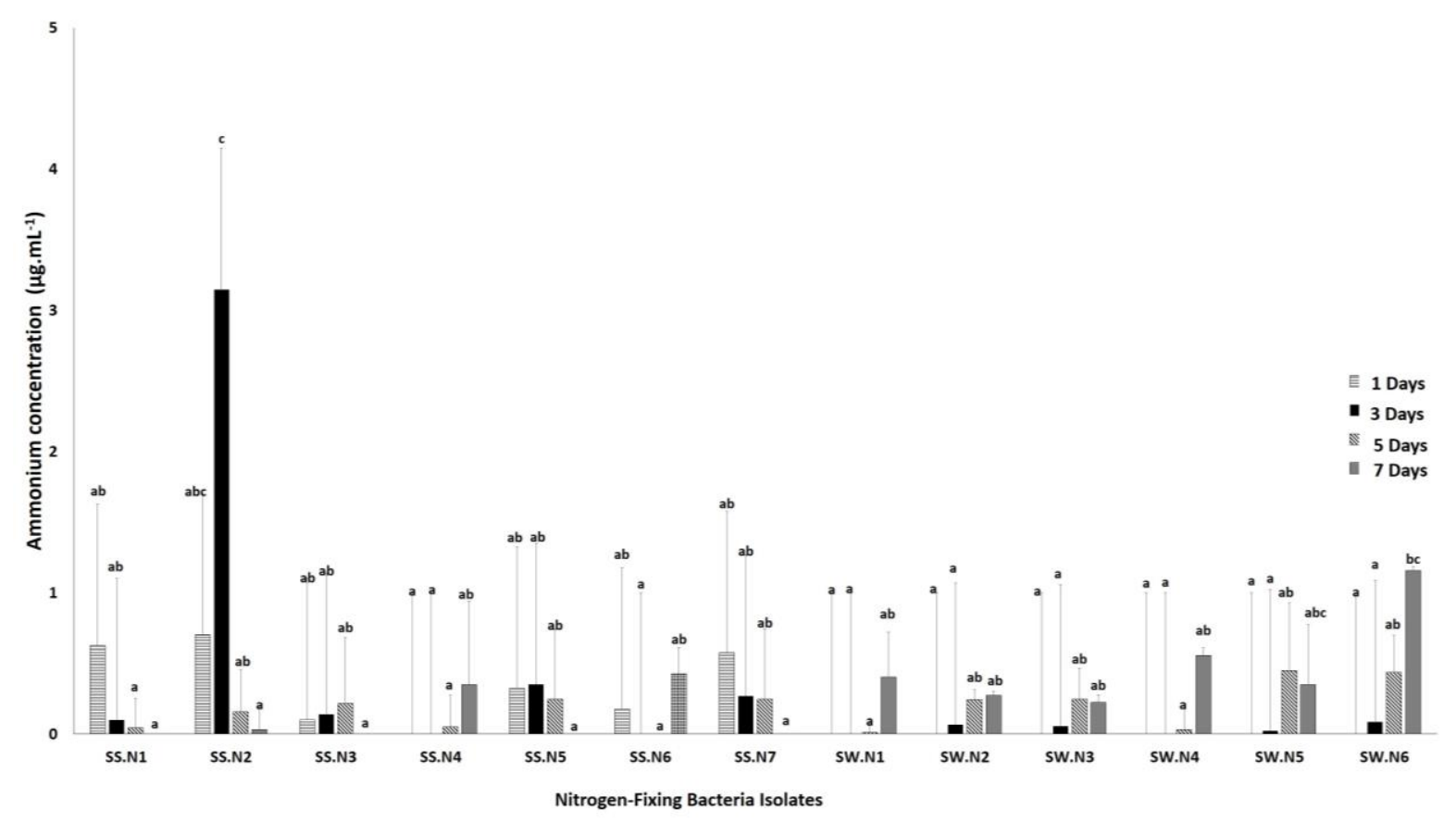

Figure 3. The concentration of Ammonium produced by Nitrogen-Fixing bacteria at various times incubation *Data were expressed as mean \pm standard deviation of three replications using Two-Way ANOVA analysis at $\alpha=0.05$. The notation above of the different histograms states the difference in potential between isolates $(p<0.05)$.

\section{Phylogenetic tree of Potential Bacteria Species Based on 16S rDNA}

The phylogeny tree of selected IAA production isolates (SS.E2 and SW.E9) were constructed from 16s rDNA sequences and compared with reference strain sequences. As shown in figure $4 a$, isolates SS.E2 and SW.E9 are in the same cluster as Bacillus cereus ATCC $14579^{\top}$.

The SS.E2 and SW.E9 isolates have sequence similarity (99.9\%) with Bacillus cereus ATCC $14579^{\top}$. The SS.P3 and SW.P5 isolates were identified as Rahnella aquatilis B35 and Kluyvera intermedia TPY16 with similarity values of $99.9 \%$, respectively (Fig. $4 \mathrm{~b}$ and $4 \mathrm{c}$ ). The SS.N2 and SW.N6 isolate was identified as Rahnella aquatilis B35 and Pseudomonas tolaasii NCPPB 2192 with similarity values $99.9 \%$ and $99.0 \%$, respectively (Fig. 4c and 4d).

The genus Pseudomonas and Bacillus are commonly found as endophytic bacteria. Plant growth promoting MQ23 and MQ23R endophytic bacteria were identified as Bacillus cereus ATCC $14579^{\top}(100 \%)$, had the $\mathrm{N}_{2}$ binding gene (nifH gene) and were able to produce siderophore, IAA, and antifungal activity [31]. Bacillus cereus
ATCC 14579 and Bacillus aerius 24K strains are known for producing IAA and ACC-Deaminase activities, respectively [32]. Endophytic Bacillus subtilis strains had PGP activity such as phosphate solubilizing, IAA production, and biological nitrogen fixation, which can significantly increase the dried weight of the aerial part, the dried weight of the radicular system, the diameter of the stem, and the number of leaves in eucalyptus plants [33]. Pseudomonas taiwanensis and Pseudomonas geniculata strains have PGP activities such as ammonia production, HCN, IAA, siderophore, phosphate solubilizing, and ACC deaminase activity [34].

Rahnella sp. are positive reported the N2 binding gene (nifH gene) based on PCR amplified by nifH and nifH-b1 primers [35]. Rahnella aquatilis from the soybean rhizosphere had phosphate solubilizing activities with the organic acid release that drop the $\mathrm{pH}$ of the culture medium [36]. The Kluyvera genus as a PGP agent has not been much explored and reported. However, the study found that Kluyvera ascorbata could be used to control Plutella xylostella (Lepidoptera: Plutellidae) [37]. 


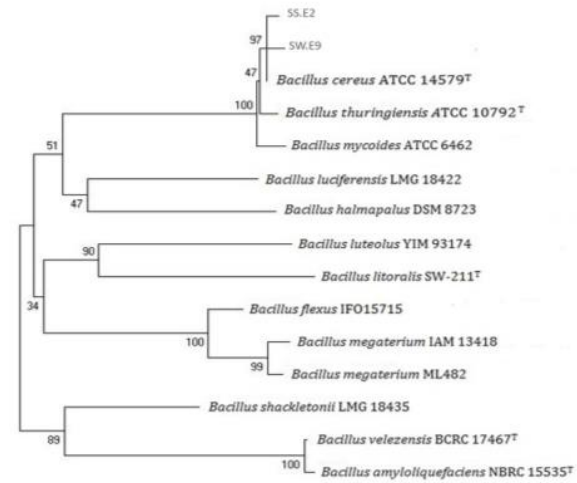

a)

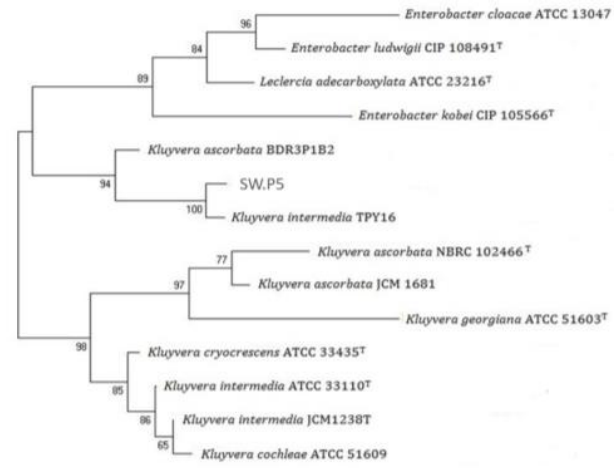

c) $\stackrel{5002}{\longmapsto}$

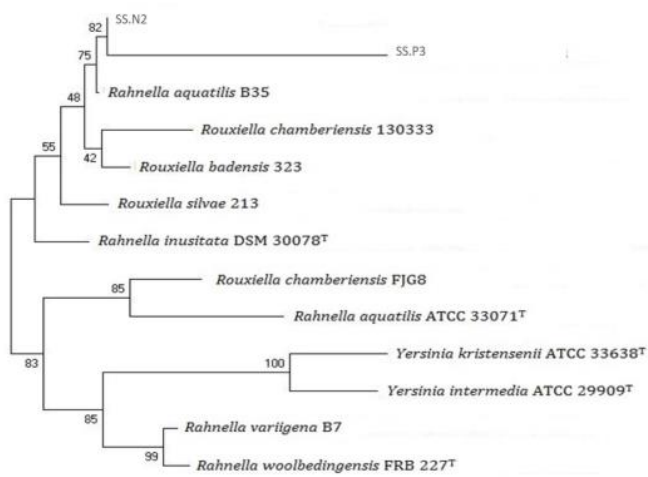

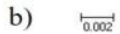

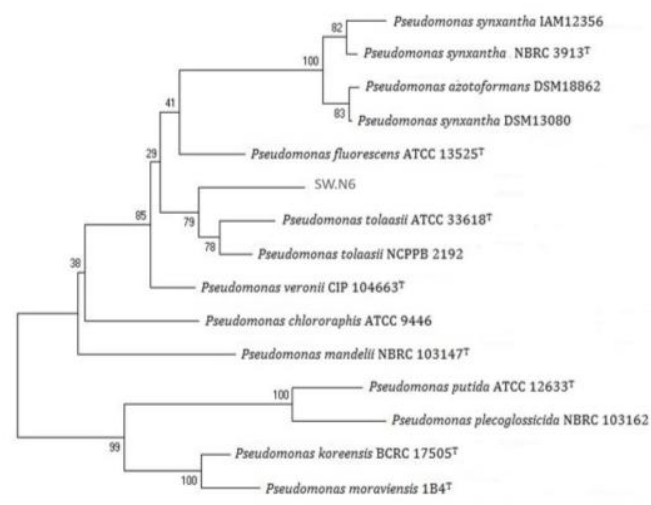

d)

Figure 4. Phylogenetic Tree of Potential Bacteria as PGP using Maximum-Likelihood algorithm with 1000 of bootsraps, MEGA 6.0 program: a) SS.E2 \& SW.E9 isolate, b) SS.P3 \& SS.N2 isolate, c) SW.P5 isolate, d) SW.N6 isolate

\section{CONCLUSIONS}

Based on the results of the study, we concluded that isolates endophytic root Robusta coffe and Arabica coffe can be developed as PGP agents. SS.E2 and SW.E9 isolates produced the highest IAA were respectively identified as Bacillus cereus ATCC 14579 (99.9\%). SS.P3 and SW.P5 isolates is the highest to dissolving phosphate that respectively identified as Rahnella aquatilis B35 (99.9\%) and Kluyvera intermedia TPY16 (99.9\%). Meanwhile, Isolates SS.N2 and SW.N6 is the highest to fixing nitrogen and respectively identified as Rahnella aquatilis B35 (99.9\%), and Pseudomonas tolaasii NCPPB 2192 (99.0\%)

\section{ACKNOWLEDGEMENT}

Kemenristekdikti (Indonesian Ministry of Research and Higher Education) for finances research through Thesis Grants. Microbiology Laboratory, Department of Biology, University of Brawijaya, for providing the facilities this research. Supervisor and colleagues for discussing consultation, supporting, and motivation in research.

\section{REFERENCES}

[1] Montavon, P., E., Duruz, G. Rumo, G. Pratz. 2003. Evolution of green coffee protein profiles with maturation and relationship to coffee cup quality. J. Agric. Food Chem. 51(8). 2328-2334.

[2] De Los Santos-Briones, C., S.M.T. Hernández Sotomayor. 2006. Coffee biotechnology. Braz. J. Plant. Physiol. 18(1). 217-227.

[3] Ayelign, A., K. Sabally. 2013. Determination of Chlorogenic Acids (CGA) in Coffee Beans using HPLC. Am. J. Res. Commun. 1(2). 7891.

[4] Kusumawati, I.A, P. Cahyo. 2019. Dampak perubahan penggunaan lahan Di UB Forest terhadap karbon biomassa mikroba dan total populasi bakteri. Jurnal Tanah dan Sumber Dya Lahan. 6(1). 1165-1172.

[5] Joergensen, R.G., J. Wu, P.C. Brookes. 2010. Measuring soil microbial biomass using an 
automated procedure. Soil Biol. Biochem. 43(5). 873-876.

[6] Guillaume, T., D. Maranguit, K. Murtilaksono, Y. Kuzyakov. 2016. Sensitivity and resistance of soil fertility indicators to land-use changes: New concept and examples from conversion of Indonesian rainforest to plantations. Ecol. Indic. 67. 4957.

[7] Khan, A.L, M. Waqas, A.R. Khan, J. Hussain, S.M. Kang, S.A. Gilani. 2013. Fungal endophyte Penicillium janthinellum LK5 improves growth of ABA-deficient tomato under salinity. World J. Microbiol. Biotechnol. 29(11). 2133-2144.

[8] Karthik, C., M. Oves, R. Thangabalu, R. Sharm, S.B. Santhosh, A.P. Indra. 2016. Cellulosimicrobium funkei-like enhances the growth of Phaseolus vulgaris by modulating oxidative damage under Chromium (VI) toxicity. J. Adv. Res. 7(6). 839-850.

[9] Puri, A., K.P. Padda, C.P. Chanway. 2016. Seedling growth promotion and nitrogen fixation by a bacterial endophyte Paenibacillus polymyxa P2b-2R and its GFP derivative in corn in a long-term trial. Symbiosis. 69(2). 123-129.

[10] Hardoim, P.R., L.S. van Overbeek, G. Berg, A.M. Pirttilä, S. Compant, A. Campisano, M. Döring, A. Sessitsch. 2015. The hidden world within Plants: Ecological and evolutionary considerations for definingfunctioning of microbial endophytes. Microbiol. Mol. Biol. 79. 293-320.

[11] Glick, B.R. 2014. Bacteria with ACC deaminase can promote plant growth and help to feed the world. Microbiol. Res. 169. 30-39.

[12] Khan, A.L., A.H. Boshra, A. Elyassi, A. Sajid, K. Al-Hosni, J. Hussain, A. Al-Harassi, I.J. Lee. 2016. Indole acetic acid and ACC deaminase from endophytic bacteria improves the growth of Solanum lycopersicum. Electron. J. Biotechn. 21. 58-64.

[13] Khan, Z., S.L. Doty. 2009.Characterization of bacterial endophytes of sweet potato plants. Plant Soil. 322. 197-207.

[14] Teaumroong, N., K. Teamtaisong, T. Sooksangun, N. Boonkerd. 2001. The diazotrophic Endophytic bacteria in thai rice. Sustainable Rice Production. 147-160.

[15] Vega, F.E, P.R. Monica, P. Francisco, S.B. Jeffrey. 2005. Endophytic bacteria in Coffea arabica L. J. Basic Microbiol. 45(5). 371-380.
[16] Rashid, S., T.C. Charles, B.R. Glick. 2012. Isolation and characterization of newplant growth-promoting bacterial endophytes. Appl. Soil Ecol. 61. 217-224.

[17] Dong, L., C. Ruiyang, X. Lina, W. Fugang, W. Guangfei, X. Jiang, W. Yong, G. Xiaotong, C. Zhongjian, C. Shilin. 2018. Diversity and composition of bacterial endophytes among plant parts of Panax notoginseng. Chin Med. 13. 41.

[18] Padder, S.A., A.B. Zahoor, Kuldeep. 2017. Isolation and characterization of indole-3acetic acid producing bacterial root endophytes associated with brown sarson (Brassica rapa L.). Int. J. Adv. Sci. Eng. Technol. 5(3). 69-74.

[19] Chairhan, M., L. Saisamorn. 2011. Screening and optimization of indole-3-acetic acid production and phosphate solubilization from Rhizobacteria aimed at improving plant growth. Curr. Microbiol. 62. 173-181.

[20] Setia, I.N., Suharjono., Y. Nurani 2018. Plant growth-promoting properties of freeliving diazotrophic rhizobacteria from Tangerine (Citrus reticulate L.) var Batu 55. Malays. J. Microbiol. 14(5). 364-371.

[21] Mihalache, G., M.Z. Maria, M. Marius, I. Iuliu, S. Marius, R. Lucian. 2015. Phosphatesolubilizing bacteria associated with runner bean rhizosphere. Arch. Biol. Sci. Belgrade. 67(3). 793-800.

[22] Rhoden, S.A., A. Garcia, M.C. Santos e Silva, J.L. Azevedo, J.A. Pamphile. 2015. Phylogenetic analysis of endophytic bacterial isolates from leaves of the medicinal plany Trichilia elegans A. Juss. (Meliaceae). Genet. Mol. Res. 14(1). 15151525.

[23] Kakade, P.D., R.C. Sushma. 2016. Phylogenetic analysis of endophytic bacteria from Nakshtra trees. Int. J. Curr. Microbiol. App. Sci. 5(12). 565-582.

[24] Bhutani, N., M. Rajat, N. Monika, S. Pooja. 2018. Optimization of IAA production by endophytic Bacillus spp for their potential use as plant growth promoters. Isr. J. Plant Sci. 65. 1-2.

[25] Khalid, A., M. Arshad, Z.A. Zahir. 2004. Screening plant growth-promoting rhizobacteria for improving growth and yield of wheat. J. Appl. Microbiol. 96. 473480.

[26] Shaikh, A.A., P.R. Parmar, B.K. Rajkumar, D.H. Patel, H.R. Desai, B.G. Solanki. 2017. Bioprospecting potential of endophytic 
bacteria from leaves of Gossypium hirsutum. Int. J. Curr. Microbiol. App. Sci. 6(10). 1718-1730.

[27] Vyas, P., A. Gulati. 2009. Organic acid production In vitro and plant growth promotion in maize under controlled environment by phosphate-solubilizing fluorescent Pseudomonas. BMC Microbiol. 9. $174-188$.

[28] Anzuay, M.S., F. Ornella, G.A. Jorge, M.L. Liliana, F. Adriana, T. Tania. 2013. Genetic diversity of phosphate-solubilizing peanut (Arachis hypogaea L.) associated bacteria and mechanisms involved in this ability. Symbiosis. 60(30). 143-154.

[29] Jha, C.K., B. Patel, M. Saraf. 2012. Stimulation of the growth ofJatropha curcas by the plant growth promoting bacterium Enterobacter cancerogenus MSA2. World J. Microbiol. Biotechnol. 28(3). 891-899.

[30] Duan, J., W. Jiang, Z. Cheng, J.J. Heikkila, B.R. Glick. 2013. The complete genome sequence of the plant growth-promoting bacterium Pseudomonas sp. UW4. PLOS ONE. 8(3). e58640.

[31] Zhao, L., Y. Xu, R. Sun, Z. Deng, W. Yang, G. Wei. 2011. Identification and characterization of the endophytic plant growth prompter Bacillus cereus strain mq23 isolated from Sophora alopecuroides root nodules. Braz. J. Microbiol. 42(2). 567575.

[32] Hemida, K.A., M.M.R. Amany. 2019. Improvement salt tolerance of safflower plants by endophytic bacteria. J. Hortic. Plant Res. 5. 38-56.

[33] Paz, I.C.P., R.C.M. Santin, A.M. Guimarães, O.P.P. Rosa, A.C.F. Dias, M.C. Quecine, J.L. Azevedo, A.T.S. Matsumura. 2012. Eucalyptus growth promotion by endophytic Bacillus spp. Genet. Mol. Res. 11(4). 3711-3720.

[34] Afzal, I., I. Irum, K.S. Zabta, Y. Azra. 2016. Plant growth-promoting potential of endophytic bacteria isolated from roots of wild Dodonaea viscosa L. Plant Growth Regul. 81(3). 399-408.

[35] Kandel, S.L., A. Firrincieli, P.M. Joubert, P.A. Okubara, N.D. Leston, K.M. McGeorge, G.S. Mugnozza, A. Harfouche, S.H. Kim, S.L. Doty. 2017. An in vitro study of bio-control and plant growth promotion potential of salicaceae endophytes. Front. Microbiol. 8. $1-16$.
[36] Kim, K.Y., J. Diann, B.K. Hari. 2006. Rahnella aquatilis, a bacterium isolated from soybean rhizosphere can solubilize hydroxyapatite. FEMS Microbiol. Lett. 153. 273-277.

[37] Laurentis, V.L., A.D.B. Sergio, A.P. Ricardo, M.V. Alessandra, C.P.V. Ana, P.D.B. Caroline, X.L.V. Haroldo. 2014. Kluyvera ascorbata: A Plant Growth-Promoting Bacteria (PGPB) to manage Plutella xylostella (L., 1758) (Lepidoptera: Plutellidae). Int. J. Agric. Sci. 1(5). 2348-3997. 